\title{
PRESERVING ABILITY OF BACILLUS SUBTILIS DURING GATHERING OF FLATTENED MOIST CORN GRAIN
}

\author{
N. O. Kravchenko' ${ }^{1}$, S. P. Chumachenko ${ }^{2}$, M. H. Perederiy ${ }^{1}$ \\ ${ }^{1}$ Institute of Agricultural Microbiology and Agroindustrial Manufacture, NAAS, Chernihiv, \\ e-mail: nat.probiotik@gmail.com \\ ${ }^{2}$ Institute of Agriculture of Carpathian Region, NAAS, Obroshyno, Pustomyty District, \\ Lviv Region, e-mail: agriwr@mail.Lviv.ua
}

The study of the influence of Bacillus subtilis 44-p on the chemical composition, nutritional value and microbiological parameters of preserved flattened moist corn grain. Using B. subtilis 44$p$, the contents of lactic acid bacteria at day 70 of preservation was $5.6 \times 10^{6}-6.0 \times 10^{6} \mathrm{CFU}$, which is 35.7-40\% higher than the corresponding control parameter. The contents of butyric acid bacteria in samples from B. subtilis 44-p at day 70 of preservation decreased to $0.3 \times 10^{6}-0.5 \times$ $10^{6} \mathrm{CFU}$ relative to control, where their number was $1.2 \times 10^{6} \mathrm{CFU}$. The use of B. subtilis 44-p facilitated decrease of contents of micromycetes in the raw materials by 90-95\% compared to control. Upon the use of B. subtilis 44-p in the flattened moist corn grain, contents of the raw protein increased by 0.24-0.25\%, crude fiber - by 0.51-0.57\% compared to the results obtained upon the use of chemical preservative - ammonium carbonate (AC), where this parameter decreased by $0.23 \%$ relative to control. Losses of dry matter were at the level of $1.15-1.5 \%$ (in the control - $1.8 \%)$. It was established that the use of B. subtilis 44-p stimulates the development of lactic acid bacteria and inhibits the growth of unwanted microorganisms in the preserved mass, facilitates the accumulation of lactic acid, ensuring retention of the feed nutritional value.

Key words: flattened wet grain of corn, preservation, nutritional value, microorganisms, Bacillus subtilis.

In recent years, the technology of preserving flattened corn grain in the early stages of maturation is becoming widespread. Flattened grain procurement is a promising, low-cost way of producing feed, since the product obtained has a high content of nutrients, is well consumed and digested by animals [1].

The process of preserving flattened corn grain is similar to the silage of the green mass of plants, based on natural lactic fermentation. However, content of sugars in the grain is much smaller than that of green mass, and gradual conversion of grain starch during the rolling and fermentation into sugar, and then to lactic acid contributes to its silage $[2,3]$. 
The quality of grain preservation is influenced by the composition of groups of epiphytic microorganisms in the raw material, the amount of lactic acid bacteria. Unfavourable feed storage conditions also affect the development of microorganisms undesired for preservation, with a significant loss of food-value and quality of feed $[3,4]$.

The use of preservatives prevents the development of putrefactive bacteria, moulds and yeast, creates conditions for the accumulation of lactic acid. In recent decades, as an alternative to chemical preservatives, the use of which is associated with a number of shortcomings, microbial preparations are used for the preservation of plant material. The guarantee of the success of the use of biopreparations is the ability of microorganisms in their composition to restrain the growth of butyric bacteria, micromycetes, as well as pathogenic and opportunistic microorganisms that can adversely affect the health of animals and humans [5-8]. Traditional microorganisms used for silage are lactic acid bacteria, but from literary sources it is known that the preservation of nutrients and the improvement of the quality of silage and haylage are significantly influenced by representatives of the species Bacillus subtilis [9].

In view of the above and in order to improve the quality and maintain food-value of feed upon the use of biological preservative, the effect of B. subtilis 44-p on the chemical composition, food-value, and microbiological parameters of preserved moist grain of flattened corn grain.

Materials and methods. The study was carried out at the Animal Feeding and Feed Technology Laboratory of the Institute of Agriculture of the Carpathian Region of the NAAS, as well as at the Laboratory of Probiotics of the Institute of Agricultural Microbiology and Agroindustrial Manufacture of the NAAS. In 2016, preservation of corn grain with a moisture content of $30.2 \%$ using preservative B. subtilis 44-p was performed under the laboratory settings (in the glass amphora). The strain was isolated from the gastrointestinal tract of livestock, deposited at the State Scientific and Control Institute of Biotechnologies and Microorganism Strains under No. 141.

The experiment provides four variants: 1 - without processing (control); 2 - preservation using chemical preservative - ammonium carbonate (AC); 3 - preservation using B. subtilis 44-p (normal range 1 - consumption of working suspension of bacteria $-5 \mathrm{~mL} / \mathrm{kg}$ of raw materials), 4 preservation using B. subtilis 44-p (normal range 2 - consumption of working suspension of bacteria - $10 \mathrm{~mL} /$ kilogram of raw material). The titre of the bacterial suspension was $7 * 10^{9} \mathrm{CFU} / \mathrm{mL}$. Samples were stored at room temperature in a dark place.

In 5, 15, 30 days of storage, the study of the number of microorganisms was carried out according to generally accepted methods $[10,11]$. In 5, 15, 30 and 70 days, chemical composition and food-value were determined according to generally accepted methods [12]. 
Results and discussion. The livestock analysis of the feed determines the actual content of nutrients, minerals and biologically active substances. The main parameters of livestock analysis that help assess the quality of feed are moisture, dry matter, crude protein, crude fat, crude fibre, crude ash and nitrogen-free extractive substances (NFES). Table 1 provided data of the analysis of the influence of B. subtilis 44-p on the preservation of the food-value of preserved flattened corn grain.

Table 1. Chemical composition of samples of control and experimental variants of flattened wet grain of corn, \%

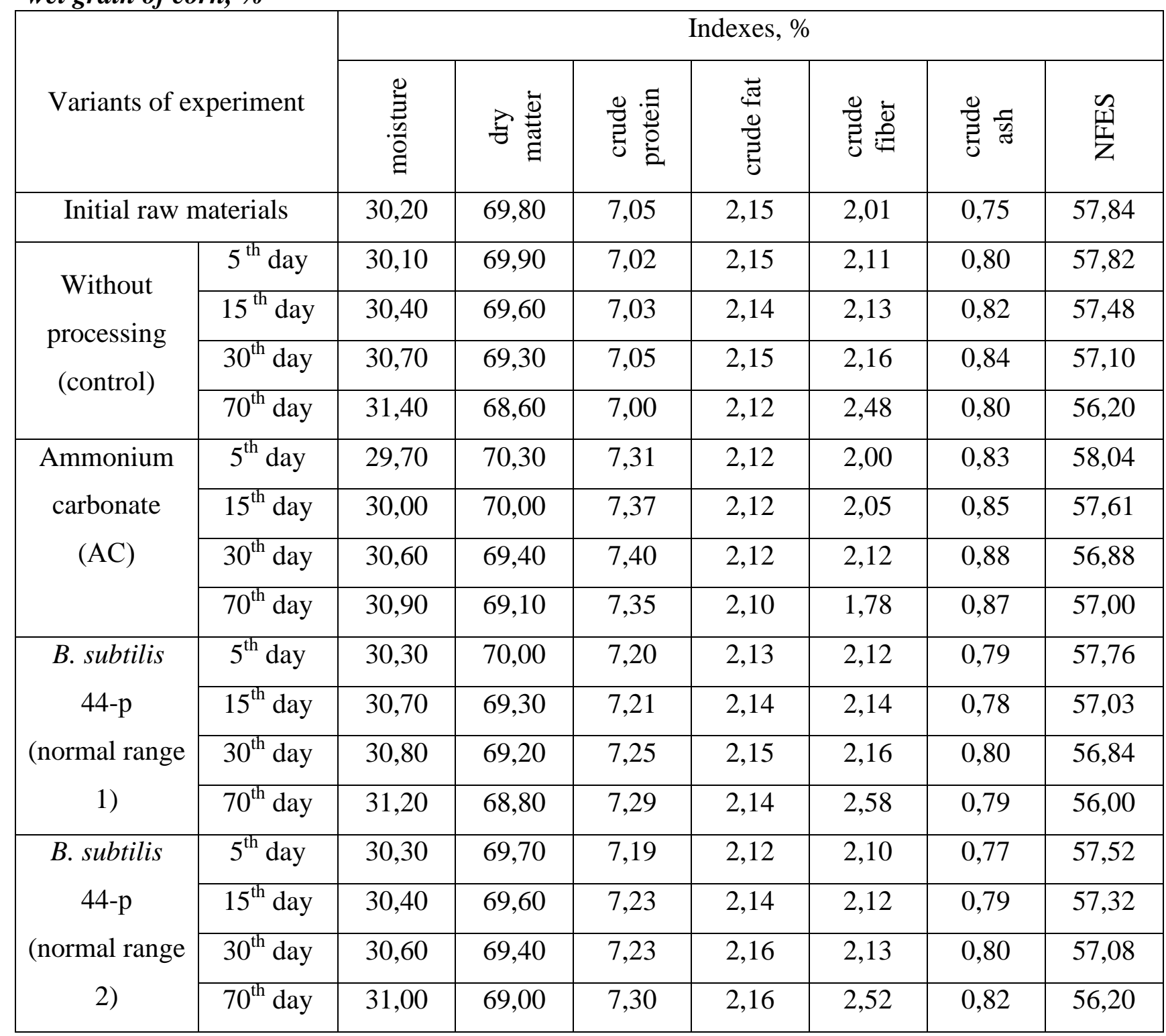

The main parameter that characterizes food-value is the content of dry matter in it. The food-value of feed is the higher, the more dry matter in it exists. In this case, regardless of the type of feed material, the food-value of the unit of dry matter in the quality flattened corn grain should be close to the raw material. The analysis of the results obtained at day 5, 15, 30 and 70 of 
preservation indicates a decrease in the dry matter content in all experimental samples. Comparative analysis of the chemical composition of samples of flattened most corn grain found that the loss of dry matter at day 70 of preservation under treatment of raw materials with suspension of $B$. subtilis 44-p (normal range 1) was $1.5 \%$, and in samples of the variant with the normal range $2-1.15 \%$. Control variant showed the highest losses of dry matter in the feed, and they comprised $1.8 \%$. Preservation of nutrients in the variant with a chemical preservative $(1.1 \%)$ was virtually at the level of the parameter obtained under the use of bacteria in the double normal range.

The content of crude protein in all studied samples exceeded parameters of the feedstock at day 5 of preservation. Thus, at day 70 of preservation, the level of crude protein increased by $0.3 \%$ in the variants with a chemical preservative, and in variant with B. subtilis 44-p (normal range 1) by $0.24 \%$, and by upon the use of the double normal range of B. subtilis $44-\mathrm{p}-$ by $0.25 \%$. Control is the only exception, where studied parameter decreased.

An important role in animal digestion, especially ruminants, is played by fibres: upon its lack, microbial processes in tripe slow down, and thus digestion is disturbed. Throughout the entire preservation process, we observe a gradual increase in the content of crude fibre in the studied samples. It should be noted that the main increase of this parameter occurred in the period from 30 to 70 days of preservation, with the only exception for chemical preservative, in which during this period the level of crude fibre decreased by $0.23 \%$ in comparison with the baseline parameters. The content of crude fibre at day 70 in variants using B. subtilis (normal range 1) and B. subtilis (normal range 2) exceeded the baseline by $0.57 \%$ and $0.51 \%$, respectively.

No less important factor affecting the quality of preservation of flattened moist corn grain is the peculiarities of fermentation processes. According to the studies conducted, in the period from day 5 to 15 of preservation, the number of pathogens lactic acid fermentation is the highest in variants using B. subtilis (Fig. 1).

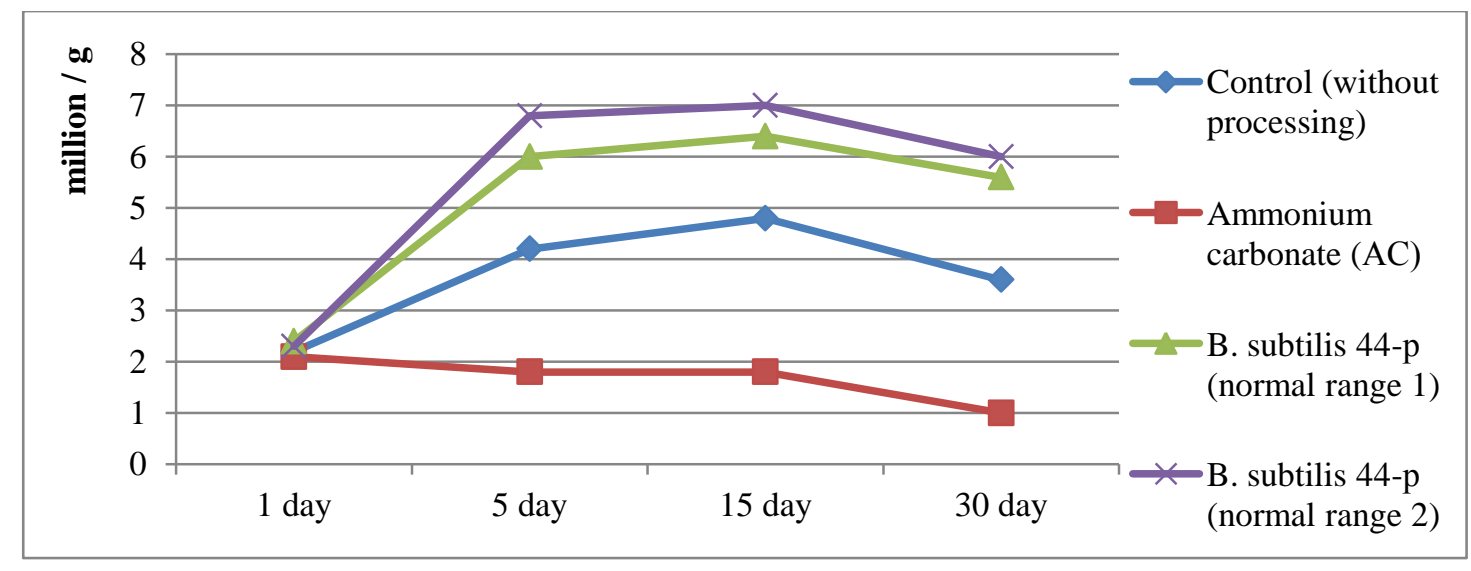

Fig.1. Number of lactic acid bacteria in the control and experimental variants of flattened wet grain of corn 
It should also be noted that in the period from day 15 to 30 of preservation, there is a gradual decrease in the number of lactic acid bacteria in all variants, which is explained by the accumulation of lactic acid, amount of which in relation to the sum of organic acids in the samples ranged from $89 \%$ in the control variant to $94 \%$ in variant with double normal range of B. subtilis cells.

The intense development of lactic acid bacteria contributes to inhibition of butyric bacteria the smallest parameters of the number of representatives of this group of microorganisms are observed in variants with B. subtilis (Fig. 2).

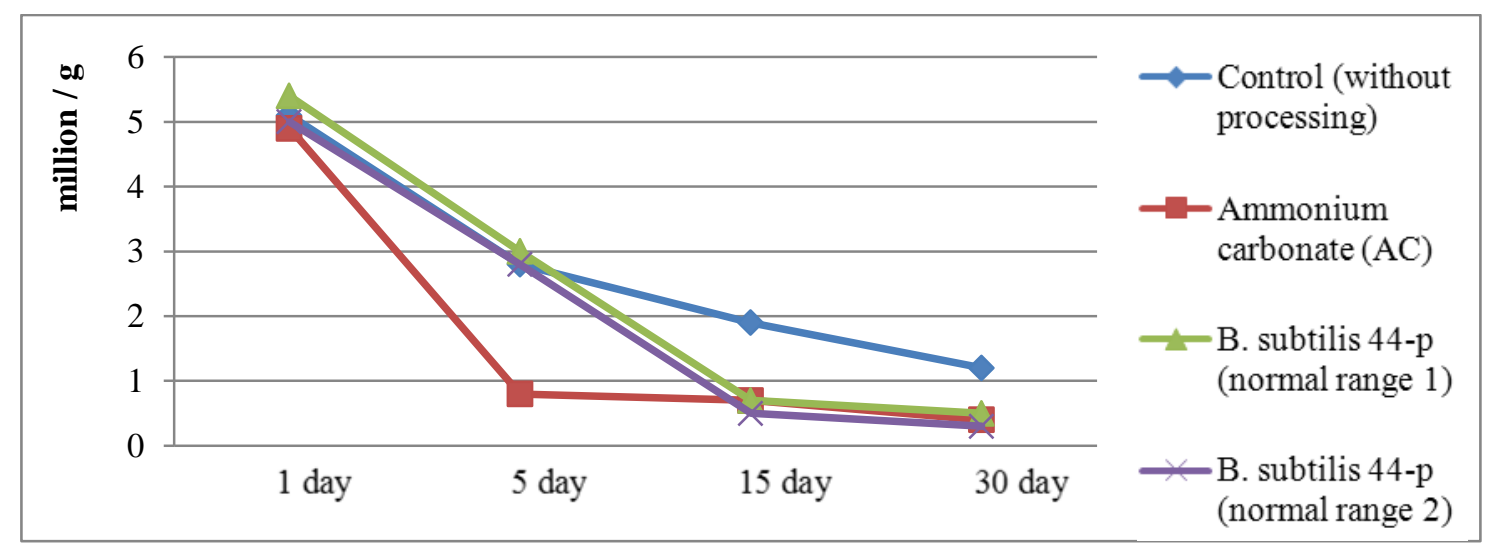

Fig.2. Number of butyric acid bacteria in control and experimental variants of flattened wet grain of corn

In variants using B. subtilis, the lowest number of fungi and yeast is observed (Fig. 3).

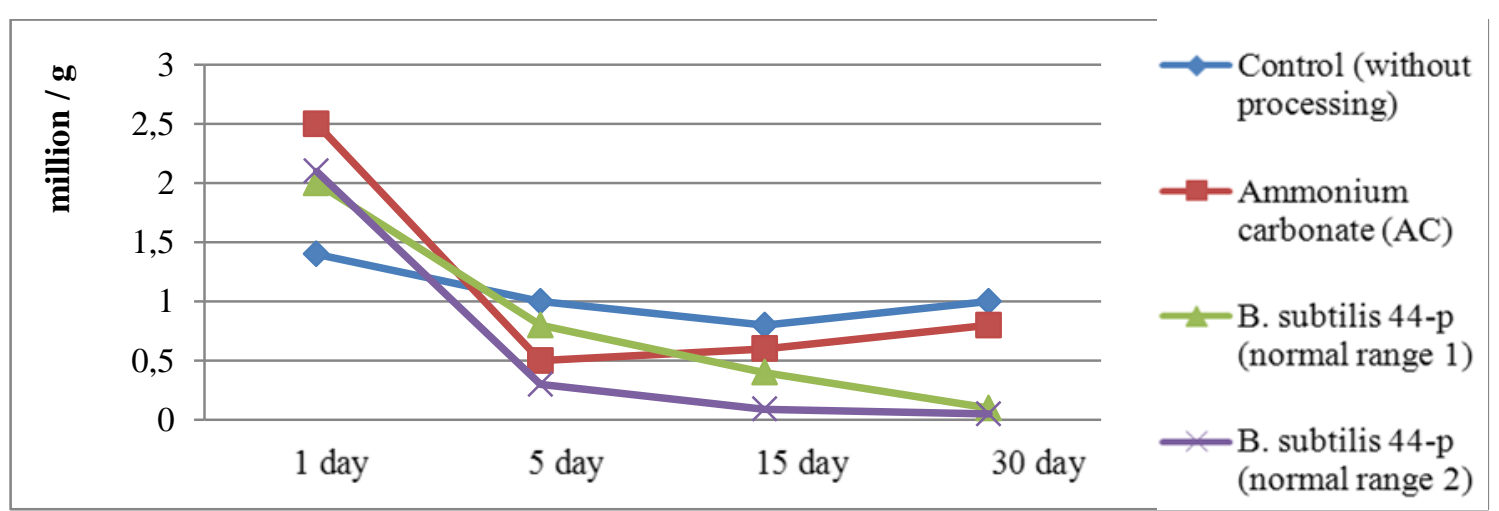

Fig.3. Number of micromycetes in the control and experimental variants of flattened wet grain of corn

At the stage of maturation of preserved flattened moist corn grain from day 5 to 30 , an important condition for obtaining a quality feed is the low number of micromycetes, since aerobic damage to the feed begins at their active development. According to the studies conducted, the lowest number of fungi and yeast is observed in variants with preservation of grain using $B$. subtilis (Fig. 3), which in our opinion, is due to the synthesis of antifungal substances by these bacteria. 
The use of AC provides suppression of virtually all studied microorganisms, including lactic acid bacteria.

Thus, the positive influence of $B$. subtilis 44-p on separate elements of the process of preservation of flattened moist corn grain has been experimentally established. The action of the experimental bacterial strain contributes to the preservation of the food-value of the feed virtually at the level with AC chemical preservative. However, the use of B. subtilis, in contrast to the chemical preservative, promotes the intensive development of lactic acid bacteria and is safe for animals and humans. Strain B. subtilis 44-p is promising for creating biopreservative and requires testing upon harvesting of flattened moist corn grain under production conditions.

1. Конюхов В. В. Технология плющения и консервирования зерна - путь к рентабельности производства / Кормопроизводство. - 2004. — № 5. - С. 29-32.

2. Oldenburg E. Mycototins in conserved forage / Oldenburg, E. // Forage conservation towards 2000 : Proc. European grassland federation conference / Pahlow, G., Honig, H. (eds.). Braunschweig (Germany), 1991. - P. 191-205.

3. Brookes R. M. Lactic acid bacteria in plant silage. Vol. 1: The lactic acid bacteria in health and disease / Brookes, R. M. \& Buckle, A. E. ; ed. Wood B. J. B. - Elsevier Science Publisher Ltd., 1992.

4. Jonsson A. The role of yeast and clostridia in silage deterioration : doctoral thesis / Jonsson, A. ; Swed. Univ. Agric. Sci., Dept. of Microbiology. - Uppsala, 1989. — Report 42.

5. Muck R. E. A lactic acid bacteria strain to improve aerobics stability of silages / Muck, R. E. // Research Summaries. - Madison : U. S. Dairy Forage Res. Center, 1996. — P. 42-43.

6. Суслова И. В. Использование консервантов различной природы при заготовке сенажа из вико-овсяной смеси / И. В. Суслова, Г. Г. Нефедов, В. М. Дуборезов // Кормопроизводство. - 2007. - № 6. - С. 30-32.

7. Суслова М. А. Влияние биологического препарата на микробиологические показатели и химический состав плющеного зерна кукурудзи / М. А. Суслова // Известия Оренбургского гос. аграрного университета. - 2012. - № 34-1, том 2. - С. 38-40.

8. Квасников Е. И. Молочнокислые бактерии и пути их использования / Е. И. Квасников, О. А. Нестеренко. - М. : Наука, 1975. - 392 с.

9. Победнов Ю. А. Эффективность применения бактерій вида Bacillus subtilis при силосовании и сенажировании трав / Ю.А. Победнов, А. А. Мамаев // Ветеринарная патология. - 2005. — № 1. - С. 90-96. 
10. Теппер Е. 3. Практикум по микробиологии : учебное пособие для вузов / Е. 3.Теппер, В. К. Шильникова, Г. И. Перевердева ; под. ред. В.К. Шильниковой. - М. : Дрофа, 2004. - 256 c.

11. Соляник Т. В. Микробиология. Микробиология кормов животного растительного происхождения : курс лекцій / Т. В. Соляник, М. А. Гласкович. - Горки : БГСХА, 2014. - $76 \mathrm{c}$.

12. Вудмаска В. Ю. Визначення поживності та якості кормів у господарстві / В. Ю. Вудмаска, П. П. Прилуцький. — К. : Урожай, 1975. — 133 с. 
КОНСЕРВИРУЮЩАЯ СПОСОБНОСТЬ ВACILLUS SUBTILIS ПРИ ЗАГОТОВКЕ ПЛЮЩЕНОГО ВЛАЖНОГО ЗЕРНА КУКУРУЗЫ

Кравченко Н.А. ${ }^{1}$, Чумаченко С.П. ${ }^{2}$, Передерий М. Г. ${ }^{1}$

${ }^{1}$ Институт сельскохозяйственной микробиологии и агропромышленного производства НААН, г. Чернигов

${ }^{2}$ Институт сельского хозяйства Карпатского региона НААН, с. Оброшино

Пустомытовский р-н, Львовская обл.

Исследовано влияние Bacillus subtilis 44$p$ на химический состав, питательность $u$ микробиологические показатели консервированного плющенного влажного зерна кукурузы. При использовании B. subtilis 44-р содержание молочнокислых бактерий на 70 сутки консервирования составило 5,6 $\times 10^{6}$

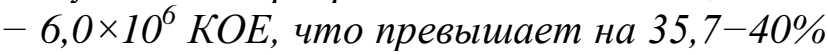
соответствующий показатель в контроле. Содержание маслянокислых бактерий в образиах с B. subtilis 44-p на 70 сутки консервирования уменьшилось до $0,3 \times 10^{6}-$ $0,5 \times 10^{6}$ КОЕ относительно контроля, где их

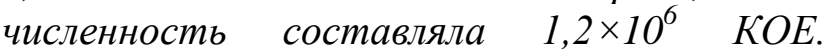
Использование B. subtilis 44-р способствовало снижению содержания в cырье микромицетов на 90-95\% по сравнению с контролем. При применении B. subtilis 44-p в плющеном влажном зерне кукурузы содержание сырого протеина выросло на 0,24-0,25\%, сырой клетчатки - на 0,51-0,57\% по сравнению с результатами, полученными при использовании химического консерванта - углеаммонийной соли (УАС), где данный показатель уменьшился на 0,23\% относительно контроля. Потери сухого вещества находились на уровне 1,15-1,5\% (в контроле - 1,8\%). Установлено, что применение B. subtilis 44-p стимулирует развитие молочнокисльх бактерий $u$ подавляет рост нежелательных микроорганизмов в консервированной массе, способствует накоплению молочной кислоты, обеспечивает сохранность питательности корма.

Ключевые слова: плющзеное влажное зерно кукурузы, консервирование, nитательность, микроорганизмы, Bacillus subtilis.
КОНСЕРВУЮЧА ЗДАТНІСТЬ ВАCILLUS SUВTILIS ПРИ ЗАГОТІВЛІ

ПЛЮЩЕНОГО ВОЛОГОГО ЗЕРНА КУКУРУДЗИ

Кравченко Н.О. ${ }^{1}$, Чумаченко С.П. ${ }^{2}$, Передерій М. Г. ${ }^{1}$

${ }^{1}$ Інститут сільськогосподарської мікробіології та агропромислового виробництва НААН, м. Чернігів

${ }^{2}$ Інститут сільського господарства

Карпатського регіону НААН, с. Оброшино

Пустомитівський р-н, Львівська обл.

Досліджено вплив Bacillus subtilis 44-p на хімічний склад, поживність та мікробіологічні показники консервованого плюшеного вологого зерна кукурудзи. При використанні B. subtilis 44-p вміст молочнокислих бактерій на 70 добу консервування становив 5,6 × $10^{6}-6,0 \times 10^{6}$ КУО, щуо перевищуе на 35,7-40\% відповідний показник у контролі. Вміст маслянокислих бактерій у зразках з B. subtilis 44-р на 70 добу консервування зменшився до 0,3 × 106 -0,5 × $10^{6}$ КУО відносно контролю, де $\ddot{\ddot{x}}$ чисельність становила $1,2 \times 10^{6}$ КУО. Використання B. subtilis 44-p сприяло зниженню вмісту в сировині мікроміцетів на 90-95\% порівняно 3 контролем. При застосуванні B. subtilis 44-p у плющеному вологому зерні кукурудзи вміст сирого протеїну зріс на 0,24-0,25\%, сирої клітковини - на 0,51-0,57\% порівняно з результатами, отриманими за використання хімічного консерванту - вуглеамонійної солі (ВАC), де даний показник зменшився на 0,23\% відносно контролю. Втрати сухої речовини знаходились на рівні 1,15-1,5\% (у контролі 1,8\%). Встановлено, щзо застосування B. subtilis 44-p стимулюе розвиток молочнокислих бактерій та пригнічує ріст небажаних мікроорганізмів у консервованій масі, сприяє накопиченню молочної кислоти, забезпечує збереженість поживності корму.

Ключові слова: плющене вологе зерно кукурудзи, консервування, поживність, мікроорганізми, Bacillus subtilis. 